\title{
DETERMINANTS OF BANK PERFORMANCE IN MALAYSIA
}

This study examines the extent to which CAMEL variables, bank-specific factors, corporate governance and macroeconomic factors influence the performance of banks in Malaysia. Three-panel data models are used for analysis, which is the pooled ordinary least squares, random effects and two-step GMM models over the period 2003 to 2016. The results indicate that capital strength, bank size, remuneration of the board of directors, the duality of the CEO-chairman and economic growth have a positive effect on bank performance, whereas management efficiency, liquidity and loan growth have a negative effect on performance. The findings suggest that the performance of banks is affected not only by bank-specific factors but also by governance and macroeconomic factors. Evidence on the relationship between governance and performance indicates that increasing the number of independent directors is simply not enough to influence performance. Our findings provide justification for regulators to consider having a set of eligibility specifications to become a bank director to ensure that governance in the banking industry is further strengthened.

Keywords: bank performance, CAMEL variables, corporate governance, return on asset, Malaysian banks

JEL Classifications: G15, G21

DOI: 10.15611 aoe.2018.2.14

\section{INTRODUCTION}

In the aftermath of the 1997-1998 Asian financial crisis, the Malaysian government started a comprehensive banking reform with the objective of strengthening local banks operating in the country. The reform was implemented by encouraging the consolidation and mergers of banks so that ultimately the number of banks in the country was supposed to be reduced and the surviving banks become bigger, stronger and more efficient. The idea is that bigger banks are seen to be more resilient and can withstand unforeseen systemic shocks as well as to be able to contribute to the stability of the financial system. It was also hoped that, as a result of the mergers and consolidation, efficiency and governance would improve, and local banks could better compete with foreign banks. It would be interesting to document

\footnotetext{
${ }^{*}$ Universiti Tunku Abdul Rahman, Kajang, Malaysia.
} 
evidence if the changes initiated by the Central Bank of Malaysia have achieved the intended objectives.

Bank performance is greatly influenced by the economic situation in which the banks operate. The U.S. sub-prime mortgage crisis and the Eurozone public debt crisis, for example, have resulted in large financial losses for the banking sector. Louzis, Vouldis and Metaxas (2012) state that banks should be able to anticipate the dynamic economic changes of an environment to be able to minimize the negative influence on bank performance. Many studies on bank performance tend to look at developed financial markets. To illustrate, Molyneux and Seth (1998) look at the U.S. market; Huong and Tripe (2002) focus on New Zealand; Williams (2003) examines Australia; Kosmidou, Pasiouras, Doumpos and Zopounidis (2006) concentrate on the U.K. while Wong, Fong, Wong and Choi (2007) study the Hong Kong market. Studies on developing markets are scarce. We managed to find only two: Sufian and Noor (2009) who look at India, whereas Sufian and Habidullah (2009) consider China.

In the local scene, there are a few studies focusing on bank performance and efficiency. For example, Bader, Mohamad, Ariff and Hassan (2008); and Ahmad and Abdul-Rahman (2012) study bank efficiency using the Data Envelopment Analysis (DEA) model. Studies on bank performance include Sufian (2009) and Rozzani and Abdul-Rahman (2013). Sufian (2009) examines the determinants of Malaysian bank efficiency during the Asian financial crisis of 1997-1998. His results show that technical efficiency is positively associated with loan intensity. Sufian's finding suggests that banks with higher loans-to-asset ratios have higher efficiency scores. Rozzani and Abdul-Rahman (2013) use the CAMEL rating as an approach to measure bank performance and find a significant negative relationship between the operational cost and performance of conventional banks. The current study extends the earlier works conducted on the Malaysian banking sector. The aim of this study is to examine the determinants of bank performance in Malaysia. The specific research objective is to find out the extent of internal factors (CAMEL variables, bank-specific factors and corporate governance) and external (macroeconomic) factors influencing bank performance.

The study contributes to the literature as follows. First, this study provides new evidence on factors affecting bank performance in a developing market. As an improvement over the previous studies the current study examines more factors. Specifically, this study looks at internal bank factors such as CAMEL and corporate governance. In addition, we look at 
the influence of macroeconomic variables on bank performance. Second, we applied different analytical tools on the panel data to identify determinants of bank performance; these include the pooled ordinary least squares, the random effects model and the two-step generalized method of moments (GMM) estimator. Our study is different from previous studies in the following ways: Sufian, Kamarudin and Nassir (2016) and Wanke, Azad and Barros (2016) both look at bank efficiency and not on performance, whereas Ali and Azmi (2016) study the performance of Islamic banks. The current study purposely excludes Islamic banks due to the fundamental differences in their operations.

The paper is organized as follows: Section 2 provides brief background information on the Malaysian banking industry. Section 3 discusses the literature leading to the development. Section 4 describes the data and methodology; Section 5 analyses the results, and Section 6 concludes the paper.

\section{AN OVERVIEW OF THE BANKING SYSTEM IN MALAYSIA}

The Malaysian banking system consists of: (i) the Central Bank, (ii) banking institutions such as commercial banks, investment banks, Islamic banks and foreign banks; (iii) other miscellaneous banking groups such as representative offices of foreign banks. The first local commercial bank (Kwong Yik Bank) was established in 1913. Foreign banks were operating in Malaysia from as early as 1875 with the establishment of the Standard Chartered Bank. The commercial banks are the largest and most significant providers of funds in the banking system.

Table 1 shows an overview of the banking system total assets in Malaysia for the period 2003 to 2016 . The table shows that total bank assets grew at an average rate of almost $9 \%$ per year. Within the banking system, commercial banks account for approximately $75 \%$ of the total assets as at the end of 2016. The commercial banks' total assets amount to RM1,820,553 million (about USD405,830 million) in the Malaysian banking system. In terms of banking activities, commercial banks provide the full range of banking services, such as depository services, trade financing, cross-border payment services, etc.

As of 2016, there were eight domestic and twenty foreign commercial banks in Malaysia. The number of domestic commercial banks is smaller than that of foreign banks due to the bank merger program orchestrated by 
Table 1

Bank assets in Malaysia

\begin{tabular}{c|c|c|c|c|c|c}
\hline \multirow{2}{*}{ Year } & \multicolumn{2}{|c|}{ Commercial banks } & \multicolumn{2}{c|}{ Investment banks } & \multicolumn{2}{c}{ Banking system } \\
\cline { 2 - 7 } & $\begin{array}{c}\text { Total assets } \\
\text { RM million }\end{array}$ & $\begin{array}{c}\text { US\$ } \\
\text { million }\end{array}$ & $\begin{array}{c}\text { Total assets } \\
\text { RM million }\end{array}$ & $\begin{array}{c}\text { US\$ } \\
\text { million }\end{array}$ & $\begin{array}{c}\text { Total assets } \\
\text { RM million }\end{array}$ & $\begin{array}{c}\text { US\$ } \\
\text { million }\end{array}$ \\
\hline 2003 & 633,047 & 166,591 & 44,768 & 11,781 & 821,208 & 216,107 \\
\hline 2004 & 769,679 & 202,547 & 43,506 & 11,449 & 881,671 & 232,019 \\
\hline 2005 & 904,450 & 239,272 & 48,433 & 12,813 & 952,886 & 252,086 \\
\hline 2006 & 981,834 & 278,021 & 67,109 & 19,003 & $1,122,558$ & 317,870 \\
\hline 2007 & $1,044,257$ & 315,819 & 77,411 & 23,412 & $1,241,601$ & 375,503 \\
\hline 2008 & $1,089,135$ & 314,415 & 60,799 & 17,552 & $1,302,113$ & 375,898 \\
\hline 2009 & $1,136,412$ & 331,847 & 63,336 & 18,495 & $1,391,510$ & 406,233 \\
\hline 2010 & $1,252,142$ & 406,078 & 65,352 & 21,194 & $1,513,524$ & 490,846 \\
\hline 2011 & $1,399,763$ & 440,593 & 70,161 & 22,084 & $1,744,398$ & 549,070 \\
\hline 2012 & $1,453,332$ & 475,256 & 61,313 & 20,050 & $1,882,332$ & 615,543 \\
\hline 2013 & $1,561,115$ & 475,732 & 55,668 & 16,964 & $2,043,367$ & 622,693 \\
\hline 2014 & $1,695,980$ & 485,259 & 54,368 & 15,556 & $2,165,005$ & 619,458 \\
\hline 2015 & $1,776,820$ & 413,984 & 51,139 & 11,915 & $2,354,287$ & 548,529 \\
\hline 2016 & $1,820,553$ & 405,830 & 50,191 & 11,188 & $2,443,605$ & 544,718 \\
\hline
\end{tabular}

Notes: The banking system total assets include also Islamic banks and finance companies.

Source: Central Bank of Malaysia Annual Reports, Monthly Statistical Bulletin.

the Central Bank of Malaysia in the aftermath of the 1997-1998 Asian financial crisis. The largest commercial bank in the country is Malayan Banking Berhad (Maybank) in which the Malaysian government has a controlling interest. In addition, the government own in full the second largest bank, CIMB Bank Berhad. Since 1994, Malaysia banking regulations require foreign commercial banks to be incorporated locally.

\section{LITERATURE REVIEW AND HYPOTHESES DEVELOPMENT}

Golin (2001) states that the bank's ROA is a key financial ratio for evaluating bank performance. Many studies use this accounting measure to study bank performance. These include Kosmidou (2008), Lee and Hsieh (2012) and Pathan and Faff (2013). In terms of determinants of performance, Athanasoglou, Brissimis and Delis (2008) take the view that bank profitability is influenced by internal and external factors. The internal factors are mainly influenced by a bank's management decisions and policy objectives. These factors include CAMEL variables, bank-specific and bank governance characteristics. The external factors encompass macroeconomic 
variables which depend on the market where the bank operates. These external determinant variables are not related to bank management, but they reflect the economic and legal environment that affects the operation and performance of banks.

\subsection{The CAMEL factors}

Previous studies argue that regulatory policies can have an impact on bank performance. Beside the Basel framework, regulators of banks also use the CAMEL framework to assess banks' management and their operational activities. The CAMEL variables consist of capital adequacy (C), asset quality (A), management efficiency (M), earnings performance (E) and liquidity (L). This study uses only four out of the five variables, which are capital adequacy, asset quality, management efficiency and liquidity. Earnings performance (E) is not included in the analysis because it is 'linked' to the dependent variable due to the common numerator in both ratios.

The capital adequacy ratio $(\mathrm{C})$ is an important variable to measure the soundness of bank capital and widely used in the analysis of bank performance. Adequacy in the bank's capital can serve as the necessary cushion to protect banks against unexpected losses and failure. In this respect, Kosmidou (2006) and Lee and Hsieh (2012) find that a higher capital ratio can have a positive effect on bank performance as measured by ROA. The positive relationships occur because a higher capital ratio increases bank creditworthiness, and this indirectly reduces bank financing costs. Alternatively, such banks may have a lesser need for external funding which then results in higher performance. Based on the discussion above, the following hypothesis can be formulated:

\section{Hypothesis H1a: Bank performance is positively related to capital adequacy ratio.}

Asset quality (A) is also referred to as credit quality. Poor asset quality or low-quality loans have been identified as a major cause of bank failure because it is directly related to bank performance. When banks have good quality assets or loans, there will be lower incidence of default and profitability will be maximized. Banks with poor asset quality will face a high incidence of defaults or non-performing loans which can lead to big losses. It is therefore important for bank management to focus on having good quality loans. Previous studies such as Miller and Noulas (1997), Wong et al. (2007) and Zhang and Daly (2014) find that loan quality is positively related to profitability and performance. The hypothesis may be written as follows: 


\section{Hypothesis H1b: Bank performance is negatively related to asset quality.}

Management efficiency (E) is referred to as the level of efficiency in bank operations. Inefficient banks would incur high operating costs that result in a lower profit margin. Inefficient banks also may compromise on asset quality that would result in a high loan default rate. It is therefore important for banks to focus on continuously improving their operational efficiency. There is an extensive literature which suggests that a variable related to expenses should be included in the performance function. This is evidenced by studies conducted by Bourke (1989) and Molyneux and Thornton (1992) who find a positive relationship between better-quality management and performance. Kosmidou, Tanna and Pasiouras (2005) and Kosmidou (2006), among others, find that poor expenses management is among the main contributors to poor profitability. Maudos and Fernández de Guevara (2004) and Maudos and Solis (2009) find that inefficient banks are associated with low interest margins because they operate on less profitable assets and high-cost liabilities. Based on this argument, the hypothesis related to the management efficiency is as follows:

\section{Hypothesis H1c: Bank performance is negatively related to management efficiency.}

In the banking sector, liquidity (L) is defined as the ability of a bank to fund increases in assets and to meet obligations as they come due without incurring unacceptable losses (Basel Committee on Banking Supervision 2008). Banks need to hold high-quality liquid assets so as to avoid insolvency. Liquidity is therefore considered an important determinant of bank performance. However, liquid assets are usually associated with a lower rate of returns, hence, higher liquidity can lead to lower bank performance. Molyneux and Thornton (1992) and Kosmidou (2008), among others, find a negative relationship between liquidity and bank performance. In Asia, Chen, Kuo and Shen (2001) analyze the banking industry in Taiwan and find that the ratio of liquid assets to deposits is negatively related to net interest margins. Elsewhere, Naceur and Kandil (2009) analyze banks in Egypt, Lin, Chung, Hsieh and Wu (2012) examine Asian banks and Sufian (2011) in Korea and all discover a negative relationship between liquidity and performance. Based on the discussion above, the hypothesis is formulated as follows: 


\section{Hypothesis H1d: Bank performance is negatively related to liquidity.}

\subsection{Bank-specific factors}

The bank-specific factors included in this study are bank size, loan growth and directors' remuneration. Bank size is generally considered a relevant determinant of performance but there is no consensus in the literature on the direction of influence. Size has been introduced to account for the existence of economies or diseconomies of scale in the market.

The economies of scale theory argues that size promotes the efficiency of operations. This argument is justified by the fact that large banks have larger resources at their disposal and are in a better position to install most modern and up-to-date technologies to reap the economies of scale in their operations, thereby reducing operational costs (Said, 2012). Studies such as Demsetz and Strahan (1997), Leung, Young and Rigby (2003), and Al-Omar and Al-Mutairi (2008) find that bank size is positively associated with performance. On the other hand, studies like those by Goddard, Molyneux and Wilson (2004) and Stiroh and Rumble (2006) document a negative association between size and performance, possibly due to the management complexity that comes with size. However, in general there seems to be a stronger justification for a positive relationship than a negative relation. In this study we test the following hypothesis:

\section{Hypothesis H2a: Bank performance is positively related to bank size.}

Apart from bank size, loan growth could also be an important factor to determine bank performance. High loan growth means asset size grows rapidly and this is directly related to the interest income of the bank. It is therefore expected that a bank with fast loan growth would be able to generate greater profits. However, an opposing view is that an increase in loan growth may also be due to relaxing the credit control and this would lead to a subsequent increase in loan losses. Empirical analyses are mixed. For example, Gul, Irshad and Zaman (2011) and Tabak, Fazio and Cajueiro (2011) find that the high growth of bank loans is related to high profitability. However, Hoffmann (2011) supports a negative relationship. We feel the argument for a positive relationship is more convincing, hence we test the following hypothesis: 


\section{Hypothesis H2b: Bank performance is positively related to loan growth.}

One variable that could have a considerable influence on bank performance but has not been incorporated in prior studies is "directors' remuneration". According to Murphy (1985) and Jensen and Murphy (1990), the issue of the pay-performance relationship is based on the principal-agent theory to justify the existence of a positive correlation. It is expected that banks with a generous remuneration package to directors would show better performance because the high remuneration will attract better qualified directors and also acts as a performance incentive. The literature on the remuneration-performance relation in the banking sector is rather scarce. John and Qian (2003), and Ang, Lauterbach and Schreiber (2002) find a positive relationship between executive pay and bank performance. Doucouliagos, Haman and Askary (2007) find no relationship between directors' remuneration and bank performance but a positive relationship exists between CEO remuneration and performance. In a recent study, Lee and Isa (2015) find a positive association between directors' remuneration and bank performance. In this respect we test the following hypothesis:

\section{Hypothesis H2c: Bank performance is positively related to directors' remuneration.}

\subsection{Bank corporate governance}

The role of corporate governance in the banking sector has been studied by Macey and O' Hara (2003), Adams and Mehran (2012), Pathan and Faff (2013), and others. These studies document that good governance has a positive impact on performance. Studies on corporate governance generally look at the board structure. The board of directors is the policymaker and highest decision maker on long-term strategies of a bank. Board members are elected by shareholders to represent their interest in monitoring and supervising the management of the bank. This study focuses on three governance measures: board size, number of independent directors, and the leadership structure of the board (duality).

Jensen (1993) argues that boards with too many directors are less likely to function effectively and run the risk of excessive CEO control and cause bureaucratic problems. Furthermore, large boards were more difficult to coordinate and could also experience problems in communication, which have a negative impact on performance. Pathan and Faff (2013) found that there is a negative relationship between board size and performance. 
However, Coles, Daniel and Naveen (2008) argued that this relationship depends on a firm's business environment. Firms with greater advisory needs or complex organizational structures and high product diversification may benefit from large boards; this is supported by Adams and Mehran (2012) who find that board size is positively associated with performance. Since banks may not have the complexity of operation as large conglomerates, and large boards may be counterproductive. Based on the above discussion we expect that the coefficient for board size in this study is likely to be negative. The hypothesis is formulated as follows:

Hypothesis H3a: Bank performance is negatively related to board size.

Corporate governance best practices suggest that the position of CEO and the chairman of the board should not be held by the same person. Having the same person holding the two positions (duality) may undermine the necessary checks and balances between the board and management. Duality could also reduce the degree of independence of the board and widen the area of self-serving and entrenchment for the CEO. In short, duality would render the board to be less effective (Jensen, 1993). However, the proponents of duality argue that duality can result in quick and smooth decision making which is important in a competitive business setting. Evidence on the duality-performance relationship is mixed.

Fama and Jensen (1983) provide evidence that duality results in board's difficulty in controlling the decisions of management. Jensen (1993) reports that for a board to be effective, it is necessary to separate the functions of the CEO and the chairman. Grove, Patelli, Victoravich and Xu (2011) and Liang, $\mathrm{Xu}$ and Jiraporn (2013) find that the CEO-chairman duality is negatively associated with the bank's performance. In contrast, Arouri, Hossain and Muttakin (2011) find that duality has an insignificant impact on banks' performance in the Gulf Cooperation Council (GCC) countries. Although evidence is mixed, we believe that duality could lead to more negative effects than positive on performance, hence we test the following hypothesis:

\section{Hypothesis H3b: Bank performance is negatively related to CEO- chairman duality.}

Another element of the governance structure is board independence. The general consensus is that an independent board of directors results in more effective corporate governance. It had been suggested that independent 
directors helped to alleviate agency problems by monitoring and controlling the behavior of management (De Andres and Vallelado, 2008). Fama and Jensen (1983) state that independent directors have the incentive to act as monitors of management as they want to protect their reputations as effective and independent decision makers. Furthermore, the independent directors were not obliged to blindly follow the views and opinions of top management, as they had less conflict of interest compared to managers (Hermalin and Weisbach, 1991). However, the literature on the effectiveness of independent directors has been inconclusive.

De Andres and Vallelado (2008), and Liang et al. (2013) support the argument of the agency theory that independent directors are effective monitors. They find a positive relation between independent directors and the banks' performance. Yet the studies by Pathan and Faff (2013) and Jermias and Ghani (2014) find that independent directors decrease a bank's performance. On the other hand, Pi and Timme (1993) and Adams and Mehran (2012) show an insignificant relationship between outside directors and a bank's performance. Based on the discussion above, there seems to be a stronger justification that more independent directors would result in better performance. The hypothesis is formulated as follows:

\section{Hypothesis H3c: Bank performance is positively related to the percentage of independent directors on the board.}

\subsection{External factors}

Other than the factors above, the macroeconomic conditions of a country can also have a significant impact on bank performance. Banks need to structure their operation so that they are able to appropriately respond to changes in the macroeconomic environment. In this study we focus on two macroeconomic variables, growth in gross domestic product (GDP) and market interest rate. High economic growth will lead to banks increasing their lending activities and possibly with a higher interest margin. Further, a high GDP growth would also result in the better debt servicing capacity of borrowers and contribute to the reduction of non-performing loans. Pasiouras and Kosmidou (2007) and Athanasoglou et al. (2008) find a positive association between GDP and bank performance. The hypothesis is formulated as follows: 


\section{Hypothesis $\mathrm{H4a}$ : Bank performance is positively related to growth in GDP.}

Market interest rates could also be an important factor to determine bank performance. It is generally believed that a rising interest rate should lead to higher bank profitability. In this study market interest rate is represented by the average bank lending rate. Bolt, Haan, Hoeberichts, Oordt and Swank (2012) find that there is a positive impact of the market lending rate on bank performance. While Flannery (1981) indicates that bank profitability changes little with changes in market lending rate. This is because the gains from increasing lending rates when interest rates rise tend to be offset by increases in deposit rates. Leung et al. (2003) find that there is a negative relationship between interest rate changes and bank performance. The authors' reason that an increase in interest rates might cause borrowers' to be reluctant to take loans. Based on the discussion, the hypothesis is formulated as follows:

Hypothesis H4b: Bank performance is negatively related to changes in the average lending rate.

\section{DATA AND METHODOLOGY}

\subsection{Data}

The data for this study include all commercial banks operating in the country from 2003 until 2016. The number of banks are 21 in the beginning but reduced to 20 later in the period of study due to a merger. Investment banks and cooperatives are not included in the study. Most of the financial data used for this study are obtained from the Bankscope database. In addition, some data were hand-collected from the bank's annual reports, such as director remuneration, board size, leadership structure (duality), and percentage of independent directors. The macroeconomics factors, namely GDP growth and average lending rate, are obtained from the publication of the Central Bank of Malaysia.

\subsection{Empirical models}

This study intends to test whether internal factors such as CAMEL variables, bank-specific factors, corporate governance and external factors (macroeconomic variables) had an effect on bank performance. Bank performance is represented by the return on asset (ROA). Different panel 
models are applied in the analysis, including the pooled cross-section and time-series OLS, the random effects and the two-step difference generalized method of moments (difference GMM).

The difference GMM model (Arellano and Bond, 1991) estimators are presented as instrumental variables in the endogenous regressors and the current values of the exogenous variables. This methodology addresses the presence of unobserved bank-specific effects, which are eliminated by taking the first-differences of all variables. Hence, the likelihood of endogeneity problems in terms of the explanatory variables being associated with dynamic models is eliminated in the GMM procedure. Arellano and Bond (1991) demonstrate that additional instruments can be obtained in a dynamic panel data model if one utilizes the orthogonality conditions that exist between the lagged values of the dependent variable and the disturbances $\mu_{i}$ - The authors propose a two-step difference GMM estimator which is employed in this study. The two-step estimator is efficient and also robust to heteroskedasticity (Roodman, 2009).

The pooled OLS model may be stated as follows:

$$
\begin{aligned}
R O A_{i t} & =\alpha+\sum_{j=1}^{J} \beta_{j} C A M E L_{i t}^{j}+\sum_{k=1}^{K} \delta_{k} B S_{i t}^{k}+ \\
& +\sum_{l=1}^{L} \gamma_{l} C G_{i t}^{l}+\sum_{m=1}^{M} \varphi_{m} M E_{i t}^{m}+\varepsilon_{i t}
\end{aligned} .
$$

The random effect model may be written as follows:

$$
\begin{gathered}
R O A_{i t}=\alpha+\sum_{j=1}^{J} \beta_{j} C A M E L_{i t}^{j}+\sum_{k=1}^{K} \delta_{k} B S_{i t}^{k}+ \\
+\sum_{l=1}^{L} \gamma_{l} C G_{i t}^{l}+\sum_{m=1}^{M} \varphi_{m} M E_{i t}^{m}+\mu_{i t}+\varepsilon_{i t}
\end{gathered} .
$$

The GMM model that includes a lag dependent variable in the explanatory variables is as follows:

$$
\begin{gathered}
R O A_{i t}=\alpha+R O A_{i t-1}+\sum_{j=1}^{J} \beta_{j} C A M E L_{i t}^{j} \\
+\sum_{k=1}^{K} \delta_{k} B S_{i t}^{k}+\sum_{l=1}^{L} \gamma_{l} C G_{i t}^{l}+\sum_{m=1}^{M} \varphi_{m} M E_{i t}^{m}+v_{i t}+\varepsilon_{i t} .
\end{gathered}
$$


The $R O A_{i t}$ refers to bank performance, $C A M E L_{i t}$ denotes the CAMEL variables, $B S_{i t}$ denotes the bank-specific factors, $C G_{i t}$ refers to corporate governance variables, $M E_{i t}$ represents the macroeconomic variables, $v_{i}$ is the unobservable bank-specific variables and $\varepsilon_{i t}$ denotes the remaining disturbance term. The subscripts $i$ denote individual banks, $i=1,2, \ldots 21$, and $t$ is the time period, $t=2003, \ldots 2016$. The definitions and expected signs of all independent variables are presented in Table 2 .

Table 2

Description of variables and their expected sign on bank performance

\begin{tabular}{|c|c|c|}
\hline Variable & Definition & $\begin{array}{l}\text { Expected } \\
\text { sign }\end{array}$ \\
\hline \multicolumn{3}{|c|}{ Dependent variable: Returns on Assets (ROA) } \\
\hline $\mathrm{ROA}$ & Net income over average total assets (in \%) & N/A \\
\hline \multirow{2}{*}{\multicolumn{3}{|c|}{$\frac{\text { Independent variables }}{\text { Internals Factors }}$}} \\
\hline & & \\
\hline \multicolumn{3}{|c|}{ CAMEL variables } \\
\hline Capital adequacy ratio & The ratio of equity to total assets (in \%) & + \\
\hline Assets quality & The ratio of non-performing loan to total loan & - \\
\hline Management efficiency & The ratio of operating expenses to operating income & - \\
\hline Bank liquidity & The ratio of liquid assets to deposits and short-term funding & - \\
\hline \multicolumn{3}{|c|}{ Bank-specific variables } \\
\hline Bank size & Natural logarithm of total assets & + \\
\hline Loan growth rate & $\begin{array}{l}\text { Change in the amount of total customer loans from year } t- \\
1 \text { to year } t(\text { in } \%)\end{array}$ & + \\
\hline Directors remuneration & $\begin{array}{l}\text { Log of total annual compensation paid to the board of } \\
\text { directors }\end{array}$ & + \\
\hline \multicolumn{3}{|c|}{ Bank governance variables } \\
\hline Board size & Natural logarithm of the number of directors on the board & - \\
\hline CEO-chairman duality & $\begin{array}{l}\text { Dummy variable that takes the value of } 1 \text {, if a chairperson } \\
\text { of the board doubles up as the CEO of the bank, and } 0 \text { if } \\
\text { otherwise }\end{array}$ & - \\
\hline Independent directors & $\begin{array}{l}\text { The percentage of independent directors measured by the } \\
\text { number of outside directors to the total number of directors } \\
\text { on the board }\end{array}$ & + \\
\hline \multicolumn{3}{|c|}{ External Factors } \\
\hline \multicolumn{3}{|c|}{ Macroeconomic variables } \\
\hline GDP growth & The growth rate of GDP (in \%) & + \\
\hline Average lending rate & The weighted average of lending rates (in \%) & - \\
\hline
\end{tabular}

Source: author's calculation. 


\section{DISCUSSION OF RESULTS}

\subsection{Descriptive statistics analysis}

Table 3 presents a summary of the descriptive statistics of the data set used in this study which spans the period 2003-2016. These statistics include mean, standard deviation, minimum and maximum. The table shows that banks' profitability as measured by ROA has a mean of $1.101 \%$. For the capital adequacy ratio, the overall mean is shown to be $16.242 \%$. This indicates that the bank's capital adequacy ratio is double the amount of the $8 \%$ statutory requirement set by the Central Bank of Malaysia. This shows that banks have more capital than is required. The average asset quality ratio of the commercial banks is 0.032 . This implies that banks have a relatively low amount of non-performing loans. Another important factor, management efficiency, proxied by the operating expenses to operating income, is 0.452 . Table 3 also shows that the average of liquid assets to deposits and shortterm funding (liquidity ratio) is 0.422 .

For the bank-specific factors, Table 3 shows that the average book value of the banks' total assets is RM75.364 million. The overall mean for loan growth is $12.058 \%$. The mean of the total amount of the directors' annual remuneration shows that most of the banks pay approximately RM6.333

Table 3

Summary of descriptive statistics

\begin{tabular}{l|c|c|c|c}
\hline \multicolumn{1}{c|}{ Variables } & Mean & Std. Dev. & Minimum & Maximum \\
\hline Return on assets (\%) & 1.101 & 0.519 & -1.373 & 3.100 \\
\hline Capital adequacy ratio (\%) & 16.242 & 3.983 & 8.570 & 33.300 \\
\hline Assets quality & 0.032 & 0.022 & 0.003 & 0.138 \\
\hline Management efficiency & 0.452 & 0.135 & 0.185 & 1.103 \\
\hline Bank liquidity & 0.422 & 0.289 & 0.067 & 1.820 \\
\hline Bank total assets (in million RM) & 75.364 & 112.218 & 896 & 735.956 \\
\hline Growth of bank loan (\%) & 12.058 & 15.155 & -34.170 & 80.200 \\
\hline Total directors' remuneration (in million RM) & 6.333 & 7.800 & 0.345 & 69.793 \\
\hline Board size & 8.488 & 1.900 & 5.000 & 13.000 \\
\hline Dummy variable, CEO-chairman duality & 0.588 & 0.493 & 0.000 & 1.000 \\
\hline Independent directors on board (\%) & 49.531 & 10.589 & 18.182 & 75.000 \\
\hline GDP growth (\%) & 5.055 & 2.002 & -1.510 & 7.154 \\
\hline Average lending rate (\%) & 5.396 & 0.751 & 4.500 & 6.496 \\
\hline
\end{tabular}

Notes: The number of observations is 289 .

Source: author's calculation. 
million, but since the maximum is RM69.793 million, the disparity indicates that there is a very wide variation among the banks in terms of director remuneration. Looking at bank governance, the size of the board varies from 5 to 13 people, with a mean of 8.488 . Considering the composition of the board, the percentage of independent directors sitting on the board varies from $18 \%$ to $75 \%$ with a mean of $49.531 \%$. This indicates that some banks have less than one-third of independent directors on their board. One-third independent directors is the guideline set by the Central Bank as well as by the 2012 Malaysian Code on Corporate Governance (MCCG). Lastly, GDP growth and average lending rate show average rates of $5.055 \%$ and $5.396 \%$, respectively.

\subsection{Regression results}

Table 4 reports the empirical results based on the estimation of pooled OLS, random effects model and the two-step difference GMM estimators. The dependent variable is the return on assets (ROA). The bottom of Table 4 contains a series of diagnostic tests on the models used in this study. The appropriateness of using the random effects rather than fixed effects models were determined by the Hausman test. The chi-square result of the Hausman test is 6.660 ( $p$-value is 0.757 ), hence, the null hypothesis of using the random effect cannot be rejected. Therefore, the random effect model is selected and yields efficient results. The results in Table 4 also suggest that the two-step difference GMM estimator indicates better overall results compared to pooled OLS and random effects estimators.

To determine the consistency of the two-step difference GMM estimators, this study uses the Hansen over-identifying test which tests the overall validity of the instruments and autocorrelation (Arellano and Bond, 1991). The Hansen test is shown to be insignificant as indicated by the $p$-value. This suggests that the model does not suffer from overidentification and the instruments are valid. The second test examines the assumption of no serial correlation in the errors of the levels. The Hansen's null hypothesis of no autocorrelation is rejected based on the Arellano-Bond order 1 test, but there is no evidence to reject the Arellano-Bond order 2 test. This indicates that the specification of the dynamic model is valid.

The last column of Tables 4 (Equation 3) shows the results of the twostep GMM model. The coefficient for lagged ROA is positive and significant at 5\% level, suggesting the lagged ROA has an impact on the current ROA. 
This confirms the appropriateness using a dynamic specification for the model. Thus, the discussion in the following section focuses on the results of the two-step GMM model (Equation 3).

\subsubsection{CAMEL variables}

Table 4 shows that the CAMEL variables encompassing the capital adequacy ratio, management quality and liquidity are significant factors influencing bank performance but asset quality ratio is not. The coefficient for capital adequacy ratio is positive showing a significant effect on bank performance. This finding supports Hypothesis 1a. It suggests that the well capitalized banks are more profitable. The capital ratio is a measure of the solvency risk of the bank and has an effect on bank profitability. The result is consistent with that from previous studies, suggesting that well-capitalized banks are safer compared to those with lower capital ratios and have lower costs of funding due to a lower prospective bankruptcy cost (Athanasoglou et al., 2008; Dietrich and Wanzenried, 2014). A lower capital ratio implies a higher leverage and risk, hence the greater cost of funding and that the profitability level is lower. Furthermore, it could be argued that banks with a sound capital position are able to attract more deposits and loan transactions and allow for a larger interest rate spread that leads to higher profitability.

As regards the asset quality variable measured by the non-performing loans to total loans, the results in Table 4 indicate a negative but insignificant relationship with bank performance, which does not support Hypothesis 1b. A possible explanation for this is that banks have a relatively low amount of non-performing loans as indicated in Table 3, hence the asset quality ratio does not have a significant impact on bank performance. It also suggests that the loan portfolios of the banks have a relatively lower risk due to a well-managed credit policy. Previous studies suggest that the coefficient of asset quality is expected to be negative because bad loans would reduce bank profitability. This is shown by Zhang and Daly (2014) who find that banks with a high credit risk or high provisions for loan losses earn less profit.

The management efficiency coefficient is negative as expected and significant at the $1 \%$ level. This result supports Hypothesis 1c. The management efficiency is measured by the ratio of operating expenses to operating income. High ratios mean being less efficient. The negative result suggests that highly efficient banks have a better performance. One implication of this result is that banks should focus more on the cost of 
management, such as administrative costs, and personnel expenses, improve the operational efficiency and hence raise the bank's profitability. This result is consistent with the results of Pasiouras and Kosmidou (2007), Athanasoglou et al. (2008) and Dietrich and Wanzenrich (2014).

The coefficient for bank liquidity in Table 4 is negative and significant, indicating that a bank with a relatively high amount of liquid assets would have a lower return. The result supports Hypothesis $1 \mathrm{~d}$. The results make sense because liquid assets tend to yield low returns and therefore by holding a high amount of liquid assets, such as cash and short-term securities, banks will have lower profitability levels. The finding is consistent with studies by Molyneux and Thornton (1992) and Kosmidou et al. (2006).

\subsubsection{Bank-specific variables}

As for bank-specific variables, the results in Table 4 indicate that all the three variables are significantly related to bank performance. For bank size the coefficient is positive, suggesting that larger banks tend to produce higher profits, hence supporting Hypothesis 2a. This result is consistent with the argument that large banks have more resources at their disposal and could use them on the most efficient technologies to reap economies of scale in their operations. The findings of this study are consistent with previous studies (e.g. Leung et al., 2003; Goddard et al., 2004; and Zhang and Daly, 2014), where size is found to have a positive impact on performance.

The coefficient for bank loan growth is negative in relation to bank performance. This suggests that higher loan growth results in lower profits. This result is against our expectation and Hypothesis $2 b$ is therefore not supported. The results indicate that banks are not able to convert high loan growth into high profits. It could be that in their pursuit for loan growth, banks may be compromising on loan quality such as relaxing on collateral requirements and/or loosening credit quality, which will lead to high nonperforming loans and costly loan maintenance. The result of this study is inconsistent with those of Gul, Irshad and Zaman (2011) and Tabak, Fazio and Cajueiro (2011), but consistent with Hoffmann's (2011). Hoffman reasons that an increase in loan volume would lead to the mismanagement of an existing loan portfolio and an increase in loan loss provisions.

Directors' remuneration appears to be an important determinant of bank performance. The study found that the directors' remuneration coefficient is positively related to the profitability of banks, hence supporting Hypothesis 2c. This result supports the argument for pay-performance causality, 
whereby remuneration acts as an effective incentive to induce high performance. Our result showing that directors' remuneration is an increasing function of bank performance is consistent with Conyon and Peck (1998), and Doucouliagos et al. (2007). The result is also consistent with the findings of Sathye (2001) that highly qualified and professional management board members may require higher remuneration packages.

\subsubsection{Corporate governance variables}

To address the issue of whether the governance of banks influence profitability, three corporate governance variables were studied: board size, CEO-chairman duality and independent directors. The results reported in Table 4 demonstrate weak evidence on the effects of corporate governance on bank performance because only one of the three variables is significant. Evidence indicates that duality is positively related, while board size and independent directors are insignificant. The finding implies that a large board is generally not helpful in generating performance in the banking sector. Our result is also consistent with Haniffa and Hudaib (2006) who find that board size may just be a symbolic representation instead of being a part of the actual bank management process.

The dummy variable for CEO-chairman duality shows that the effect of duality on profitability is positive and significant. This suggests that duality actually improves bank's performance. This finding contrasts with our expectations and contradicts corporate governance best practices. Maybe this is unique to the banking sector but certainly more studies need to be conducted to obtain more evidence. Nevertheless, our finding in this study is consistent with Stewart (1991) and Dahya et al. (1996), who stated that the role of CEO-chairman duality sharpened decision-making and promoted rapid operations in decision-making.

Regarding independent directors, the estimated coefficient is insignificant. This implies that an increase in the number of independent directors does not affect bank profitability. This result is also counterintuitive because, as indicated by governance best practices, independent directors are expected to bring more objective decision making into the firm and help to enhance performance. Our results may indicate that independent bank directors may be elected simply to fulfill regulatory requirements (Pathan and Faff, 2013) as opposed to enhancing performance. To summarize, Hypotheses $3 \mathrm{a}, 3 \mathrm{~b}$ and $3 \mathrm{c}$ are all not supported. 
Table 4

\section{Regression results}

This table contains the panel model with pooled ordinary least squares, random effects and two-step difference GMM regression results that examine internal and external factors on banks' performance. The dependent variable is the return on assets (ROA)

\begin{tabular}{|c|c|c|c|c|}
\hline & $\begin{array}{l}\text { Expected } \\
\text { sign }\end{array}$ & $\begin{array}{c}\text { Equation (1) } \\
\text { Pooled } \\
\text { OLS model }\end{array}$ & $\begin{array}{l}\text { Equation (2) } \\
\text { Random } \\
\text { effects model }\end{array}$ & $\begin{array}{l}\text { Equation (3) } \\
\text { Two-step } \\
\text { GMM model }\end{array}$ \\
\hline \multicolumn{2}{|l|}{ Intercept } & $1.188 * *(0.020)$ & $1.133 * *(0.029)$ & \\
\hline $\mathrm{ROA}_{t-1}$ & & & & $0.170 * *(0.022)$ \\
\hline \multicolumn{5}{|l|}{ CAMEL variables } \\
\hline Capital adequacy ratio & + & $0.333 * * *(0.000)$ & $0.351 * * *(0.000)$ & $0.345 * * *(0.000)$ \\
\hline Assets quality & - & $-0.030(0.213)$ & $-0.027(0.119)$ & $-0.043(0.121)$ \\
\hline Management efficiency & - & $-0.723 * * *(0.000)$ & $-0.761 * * *(0.000)$ & $-0.727 * * *(0.000)$ \\
\hline Bank liquidity & - & $-0.096 * *(0.016)$ & $-0.198 * *(0.048)$ & $-0.196^{* *}(0.020)$ \\
\hline \multicolumn{5}{|c|}{ Bank-specific variables } \\
\hline Bank size & + & $0.072 * *(0.023)$ & $0.068 * *(0.042)$ & $0.104 * * *(0.000)$ \\
\hline Loan growth rate & + & $-0.004 * * *(0.001)$ & $-0.005 * * *(0.001)$ & $-0.012 * *(0.028)$ \\
\hline Directors' remuneration & + & $0.100 * *(0.026)$ & $0.098 * *(0.047)$ & $0.073 * *(0.043)$ \\
\hline \multicolumn{5}{|c|}{ Corporate governance variables } \\
\hline Board size & - & $-0.224(0.162)$ & $-0.083(0.519)$ & $-0.231(0.731)$ \\
\hline CEO-chairman DUAL & - & $0.175 * *(0.017)$ & $0.175 * *(0.015)$ & $0.176^{* * *}(0.001)$ \\
\hline Independent directors & + & $0.072(0.799)$ & $0.084(0.770)$ & $0.051(0.200)$ \\
\hline \multicolumn{5}{|c|}{ Macroeconomic variables } \\
\hline GDP growth rate & + & $0.018(0.184)$ & $0.021 *(0.086)$ & $0.023 * *(0.039)$ \\
\hline Average lending rate & - & $-0.044(0.881)$ & $-0.131(0.644)$ & $0.049(0.531)$ \\
\hline \multicolumn{2}{|l|}{$F$-statistic } & 10.318 & 9.101 & 25.693 \\
\hline \multicolumn{2}{|l|}{ Adjusted $R$-square } & 0.310 & 0.284 & \\
\hline \multicolumn{2}{|c|}{ Hausman test } & & $6.660(0.757)$ & \\
\hline \multicolumn{2}{|c|}{ Arellano-Bond order 1 test ( $p$-value) } & & & $(0.015)$ \\
\hline \multicolumn{2}{|c|}{ Arellano-Bond order 2 test ( $p$-value) } & & & $(0.574)$ \\
\hline \multicolumn{2}{|c|}{ Hansen test ( $p$-value) } & & & $(0.590)$ \\
\hline \multicolumn{2}{|l|}{ Number of instruments } & & & 14 \\
\hline \multicolumn{2}{|l|}{ Number of banks } & 21 & 21 & 21 \\
\hline \multicolumn{2}{|c|}{ Number of pooled observations } & 289 & 289 & 289 \\
\hline
\end{tabular}

Notes: The numbers in the parentheses are $p$-values. ${ }^{*}, * *$ and $* * *$ denote significance at the $10 \%, 5 \%$ and $1 \%$ levels, respectively. The Hansen test is the test for the over-identifying restriction in the GMM estimation. Arellano-Bond order 1 (2) is tested for first (second) order serial correlation $\left(\mathrm{H}_{0}\right.$ : no autocorrelation).

Source: author's estimation. 


\subsubsection{Macroeconomic variables}

For the macroeconomic variables (external factors) our results indicate a positive relation with GDP growth and performance but an insignificant relation with changes in lending rates. The effect of GDP growth on bank profitability was found to be statistically significant and positive, which means that the bank's profits increase during good economic conditions. This result supports Hypothesis 4a. During economic growth, banks not only will have increased their business but are also capable of charging higher lending rates. In a similar context, banks could successfully collect their loans as businesses had increased profits. The results simply mean that in good times, profits will increase. This is in line with the literature which indicates that a rise in the GDP rate boosts bank performance (e.g. Pasiouras and Kosmidou, 2007; and Athanasoglou et al., 2008).

As regards the average lending rate, the coefficient of this variable does not indicate a significant impact on performance. Therefore, Hypothesis $4 \mathrm{~b}$ is not supported. This finding is consistent with Flannery (1981). The result suggests that when market interest rates change, the borrowing interest rate and funding costs also adjust simultaneously. Thus, the effect of a change in interest rates cancel each other out, and bank performance is not sensitive to market interest rates.

\section{CONCLUSION}

This paper examines the extent to which CAMEL variables, bankspecific factors, corporate governance and macroeconomic factors contribute to bank performance. The sample consists of 21 commercial banks operating in Malaysia between 2003 and 2016. Different panel data models were applied in the analysis, which is the pooled OLS, the random effects model and the two-step GMM technique to estimate bank performance. Overall, the results show that the two-step GMM model is the preferred method of estimation.

The results indicate that large banks with good capitalization tend to be more profitable. This study also found that the remuneration of the board of directors is positively related to bank performance. On the other hand, bank operating expenses, high liquidity and loan growth had significant negative effects on bank performance. The corporate governance of banks is also found to have an effect on performance. Specifically, against the expectations, the results show that CEO-chairman duality improves bank 
profitability. The estimated coefficients for board size and for independent directors are insignificant in explaining profitability. Finally, a macroeconomic factor, the GDP growth, had a positive and significant effect on bank performance. Our overall findings suggest that the profitability of banks is affected not only by bank-specific factors but also by their governance and macroeconomic factors.

Our results lead to the conclusion that banks should put more emphasis on cost-efficient management practices. Banks need to focus on cost control and operating efficiency by reducing production cost which in turn earns higher profits through optimizing the input-output ratio. The findings of bank-specific factors indicate that loan growth is negatively associated with bank performance. This suggests that banks should carefully monitor loan quality since high loan growth is directly associated with bank risk. Our evidence on bank governance indicates that increasing the number of independent directors is simply not enough to achieve superior performance. Independent directors should be appointed for their monitoring and advisory capabilities, rather than just to demonstrate compliance with regulatory requirements. It is suggested that there should be a set of specifications drawn up by the regulators to ensure only qualified directors are appointed to the board. This would certainly improve governance in the banking industry.

\section{REFERENCES}

Adams, R. B., Mehran, H., Bank Board Structure and Performance: Evidence for Large Bank Holding Companies, "Journal of Financial Intermediation”, 21(2), pp. 243-267, 2012.

Ahmad, S., Abdul-Rahman, A. R., The Efficiency of Islamic and Conventional Commercial Banks in Malaysia, "International Journal of Islamic and Middle Eastern Finance and Management", 5(3), pp. 241-263, 2012.

Ali, M., Azmi, W., Religion in the Boardroom and Its Impact on Islamic Banks' Performance, "Review of Financial Economics", 31, pp. 83-88, 2016.

Al-Omar, H., Al-Mutairi, A., Bank Specific Determinants of Profitability: The Case of Kuwait, "Journal of Economic and Administrative Sciences", 22(2), pp. 20-34, 2008.

Ang, J., Lauterbach, B., Schreiber, B. Z., Pay at the Executive Suite: How Do US Banks Compensate Their Top Management Teams?, "Journal of Banking and Finance", 26, pp. 1143-1163, 2002.

Arellano, M., Bond, S., Some Tests of Specification for Panel Data: Monte Carlo Evidence and an Application to Employment Equations, "Review of Economic Studies", 58(2), pp. 277$-297,1991$.

Arouri, H., Hossain, M., Muttakin, M., Ownership Structure, Corporate Governance and Bank Performance: Evidence from GCC Countries. "Corporate Ownership and Control", 8(4), pp. 365-372, 2011. 
Athanasoglou, P. P., Brissimis, S. N., Delis, M. D., Bank-specific, Industry-specific and Macroeconomic Determinants of Bank Profitability, "International Financial Markets, Institutions and Money", 18, pp. 121-136, 2008.

Bader, M. K. I., Mohamad, S., Ariff, M., Shah, T. H., Cost, Revenue, and Profit Efficiency of Islamic versus Conventional Banks: International Evidence Using Data Envelopment Analysis, "Islamic Economic Studies", 15(2), pp. 23-76, 2008.

Basel Committee on Banking Supervision, Principles for Sound Liquidity Risk Management and Supervision, "Bank for International Settlements", pp. 44, 2008.

Bolt, W., Haan, L. D., Hoeberichts, M., Oordt, M. R. C., Swank, J., Bank Profitability during Recession, "Journal of Banking and Finance", 36(9), pp. 2552-2564, 2012.

Bourke, P., Concentration and Other Determinants of Bank Profitability in Europe, North America and Australia, "Journal of Banking and Finance", 13, pp. 65-79, 1989.

Chen, H. J., Kuo, C. J., Shen, C. H., Determinants of Net Interest Margins in Taiwan Banking Industry, "Journal of Financial Studies", 9, pp. 47-83, 2001.

Coles, J., Daniel, N., Naveen, L., Boards: Does One Size Fit All?, "Journal of Financial Economics", 87(2), pp. 329-356, 2008.

Conyon, M. J., Peck, S. I., Board Control, Remuneration Committee, and Top Management Compensation, “Academy of Management Journal”, 41(2), pp. 146-157, 1998.

Dahya, J., Lonie, A. A., Power, D. M., The Case for Separating the Roles of Chairman and CEO: An Analysis of Stock Market and Accounting Data, "Corporate Governance - An International Review", 4(2), pp. 71-77, 1996.

De Andres, P., Vallelado, E., Corporate Governance in Banking: The Role of the Board of Directors, "Journal of Banking and Finance", 32, pp. 2570-2580, 2008.

Demsetz, R. S., Strahan, P. E., Diversification, Size, and Risk at Bank Holding Companies, "Journal of Money, Credit and Banking", 29(3), pp. 300-313, 1997.

Dietrich, A., Wanzenried, G., The Determinants of Commercial Banking Profitability in Low-, Middle-, and High-income Countries, "The Quarterly Review of Economics and Finance", 54, pp. 337-354, 2014.

Doucouliagos, H., Haman, J., Askary, S., Directors Remuneration and Performance in Australian Banking, "Corporate Governance", 15(6), pp. 1363-1379, 2007.

Fama, E. F., Jensen, M. C., Separation of Ownership and Control, "Journal of Law and Economics", 26(2), pp. 327-349, 1983.

Flannery, M. J., Market Interest Rates and Commercial Bank Profitability: An Empirical Investigation, "Journal of Finance", 36, pp. 1085-101, 1981.

Goddard, J., Molyneux, P., Wilson, J. O. S., Dynamic of Growth and Profitability in Banking, "Journal of Money, Credit and Banking", 36, pp. 1069-1090, 2004.

Golin, J., The Bank Credit Analysis Handbook: A Guide for Analysts, "Bankers and Investors", John Wiley \& Sons, Asia, 2001.

Gul, S., Irshad, F., Zaman, K., Factors Affecting Bank Profitability in Pakistan, "The Romanian Economic Journal", 14(39), pp. 61-87, 2011.

Grove, H., Patelli, L., Victoravich, L. M., Xu, P., Corporate Governance and Performance in the Wake of the Financial Crisis: Evidence from US Commercial Banks, "Corporate Governance - An International Review", 19(5), pp. 418-436, 2011. 
Haniffa, R., Hudaib, M., Corporate Governance Structure and Performance of Malaysian Listed Companies, "Journal of Business Finance \& Accounting", 33(7\&8), pp. 10341062, 2006.

Hermalin, S., Weisbach, M., The Effects of Board Composition and Direct Incentives on Firm Performance, "Financial Management", 22, pp. 101-112, 1991.

Hoffmann, P. S., Determinants of the Profitability of the US Banking Industry, "International Journal of Business and Social Science", 2(22), pp. 255-269, 2011.

Huong, M. T., Tripe, D., Factors Influencing the Performance of Foreign-owned Banks in New Zealand, "Journal of International Financial Markets, Institutions and Money", 12(4\&5), pp. 341-357, 2002.

Jensen, M. C., The Modern Industrial Revolution, Exit, and the Failure of Internal Control Systems, "Journal of Finance", 43(3), pp. 831-880, 1993.

Jensen, M. C., Murphy, K. J., Performance Pay and Top-management Incentives, "Journal of Political Economy", 98(2), pp. 225-264, 1990.

Jermias, J, Ghani, L., The Impact of Board Capital and Board Characteristics on Firm Performance, "The British Accounting Review", 46(2), pp. 135-153, 2014.

John, K., Qian, Y. M., Incentive Features in CEO Compensation in the Banking Industry, "Economic Policy Review", 9(1), pp. 109-121, 2003.

Kosmidou, K., Pasiouras, F., Doumpos, M., Zopounidis, C., Assessing Performance Factors in the UK Banking Sector: A Multicriteria Approach, "Central European Journal of Operational Research”, 14(1), pp. 25-44, 2006.

Kosmidou, K., Tanna, S., Pasiouras, F., Determinants of Profitability of UK Domestic Banks: Panel Evidence from the Period 1995-2002 [in:] Proceedings of the 37th Annual Conference of the Money Macro and Finance (MMF) Research Group, Rethymno, Greece, September 1-3, 2005.

Kosmidou, K., The Determinants of Banks' Profits in Greece during the Period of EU Financial Integration, "Managerial Finance", 34(3), pp. 146-159, 2006.

Kosmidou, K., The Determinants of Banks' Profits in Greece during the Period of EU Financial Integration, "Managerial Finance", 34(3), pp. 146-159, 2008.

Liang, Q., Xu, P., Jiraporn, P., Board Characteristics and Chinese Bank Performance, "Journal of Banking and Finance", 37, pp. 2953-2968, 2013.

Lee, C. C., Hsieh, M. F., The Impact of Bank Capital on Profitability and Risk in Asian Banking, "Journal of International Money and Finance", 30(1), pp. 1-31, 2012.

Lee, S. P., Isa, M., Directors' Remuneration, Governance and Performance: The Case of Malaysian Banks, "Managerial Finance", 41(1), pp. 26-44, 2015.

Leung, M. K., Young, T., Rigby, D., Explaining the Profitability of Foreign Banks in Shanghai, "Managerial Decision Economics", 24(1), pp. 15-24, 2003.

Lin, J. R., Chung, H. M., Hsieh, M. H., Wu, S. H., The Determinants of Interest Margins and Their Effect on Bank Diversification: Evidence from Asian Banks, "Journal of Financial Stability”, 8, pp. 96-106, 2012.

Louzis, D. P., Vouldis, A. T., Metaxas, V. L., Macroeconomics and Bank Specific Determinants of Non-performing Loans in Greece: A Comparative Study of Mortgage, Business and Consumer Loan Portfolios, "Journal of Banking and Finance”, 36(4), pp. 1012-1027, 2012. 
Macey, J., O'Hara, M., The Corporate Governance of Banks, "Economic Policy Review", 9(1), pp. 91-107, 2003.

Maudos, J., Fernández de Guevara, J., Factors Explaining the Interest Margin in the Banking Sectors of the European Union, "Journal of Banking and Finance", 28, pp. 2259-2281, 2004.

Maudos, J., Solis, S., The Determinants of Interest Income in the Mexican Banking System: An Integrated Model, "Journal of Banking and Finance", 33, pp. 1920-1931, 2009.

Miller, S. M., Noulas, A. Portfolio Mix and Large Bank Profitability in the USA, "Applied Economics", 29(4), pp. 505-12, 1997.

Molyneux, P., Thornton, J., Determinants of European Bank Profitability: A Note, "Journal of Banking and Finance", 16, pp. 1173-1178, 1992.

Molyneux, P., Seth. R., Foreign Banks, Profits, and Commercial Credit Extensions in the United States, “Applied Financial Economics”, 8, pp. 533-539, 1998.

Murphy, K. J., Corporate Performance and Managerial Remuneration: An Empirical Analysis, "Journal of Accounting and Economics", 7(1-3), pp. 11-42, 1985.

Naceur, S. B., Kandil, M., The Impact of Capital Requirements on Banks' Cost of Intermediation and Performance: The Case of Egypt, "Journal of Economics and Business", 61, pp. 70-89, 2009.

Pathan, S., Faff, R., Does Board Structure in Banks Really Affect Their Performance?, "Journal of Banking and Finance", 37(5), pp. 573-1589, 2013.

Pasiouras, F., Kosmidou, K., Factors Influencing the Profitability of Domestic and Foreign Commercial Banks in the European Union, "Research in International Business and Finance", 21(2), pp. 222-237, 2007.

Pi, L., Timme, S. G., Corporate Control and Bank Efficiency, "Journal of Banking and Finance", 17, pp. 515-530, 1993.

Roodman, D., How to Do xtabond2: An Introduction to Difference and System GMM in Stata, "The Stata Journal", 9(1), pp. 86-136, 2009.

Rozzani, N., Abdul-Rahman, R., Determinants of Bank Performance: Conventional versus Islamic, "Jurnal Pengurusan", 39, pp. 129-139, 2013.

Said, A., Comparing the Change in Efficiency of the Western and Islamic Banking Systems, "Journal of Money, Investment and Banking", 23, pp. 149-180, 2012.

Sathye, M., X-efficiency in Australian Banking: An Empirical Investigation, "Journal of Banking and Finance", 25, pp. 613-630, 2001.

Stewart, R., Chairman and Chief Executives: An Exploration of Their Relationships, "Journal of Management Studies", 28(5), pp. 511-528, 1991.

Stiroh, K. J., Rumble, A., The Dark Side of Diversification: The Case of US Financial Holding Companies, "Journal of Banking and Finance", 30, pp. 2131-2161, 2006.

Sufian, F., Determinants of Bank Efficiency during Unstable Macroeconomic Environment: Empirical Evidence from Malaysia, "Research in International Business and Finance", 23(1), pp. 54-57, 2009.

Sufian, F., Habibullah, M. S., Bank-specific and Macroeconomic Determinants of Bank Profitability: Empirical Evidence from the China's Banking Sector, "Frontiers of Economics in China", 4(2), pp. 274-291, 2009. 
Sufian, F., Kamarudin, F., Nassir, A., Determinants of Efficiency in the Malaysian Banking Sector: Does Bank Origins Matter? "Intellectual Economics”, 10, pp. 38-54, 2016.

Sufian, F., Noor, M. A. N. M., Determinants of Bank Performance in a Developing Economy: Does Bank Origin Matter?, "Business and International Management", 13(1), pp. 1-23, 2009.

Sufian, F., Profitability of the Korean Banking Sector: Panel Evidence on Bank-specific and Macroeconomic Determinants, "Journal of Economics and Management", 7(1), pp. 43-72, 2011.

Tabak, B. M., Fazio, D. M., Cajueiro, D. O., The Effects of Loan Portfolio Concentration on Brazilian Banks Return and Risk, "Journal of Banking and Finance", 35(11), pp. 30653076, 2011.

Wanke, P., Azad, M. A. D., Barros, C. P., Financial Distress and the Malaysian Dual Banking System: A Dynamic Slacks Approach, "Journal of Banking and Finance", 66, pp. 1-18, 2016.

Williams, B., Domestic and International Determinants of Bank Profits: Foreign Banks in Australia, "Journal of Banking and Finance", 27(6), pp. 1185-1210, 2003.

Wong, J., Fong, T., Wong, E., Choi, K. F., Determinants of the Performance of Banks in Hong Kong, "Hong Kong Monetary Authority Quarterly Bulletin", 3, pp. 5-13, 2007.

Zhang, X. X., Daly, K., The Impact of Bank-specific and Macroeconomic Factors on China's Bank Performance, "The Chinese Economy”, 47(5-6), pp. 5-28, 2014.

Received: July 2015, revised: October 2017 